Historic, Archive Document

Do not assume content reflects current scientific knowledge, policies, or practices. 




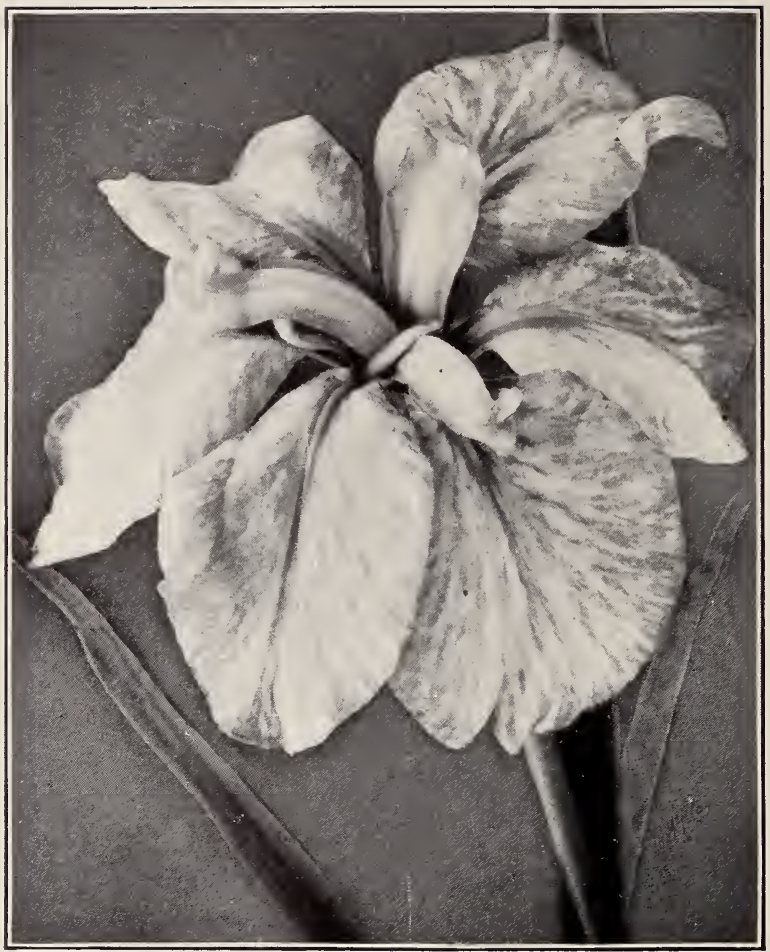

Iris Kæmpferi (see page 24) 


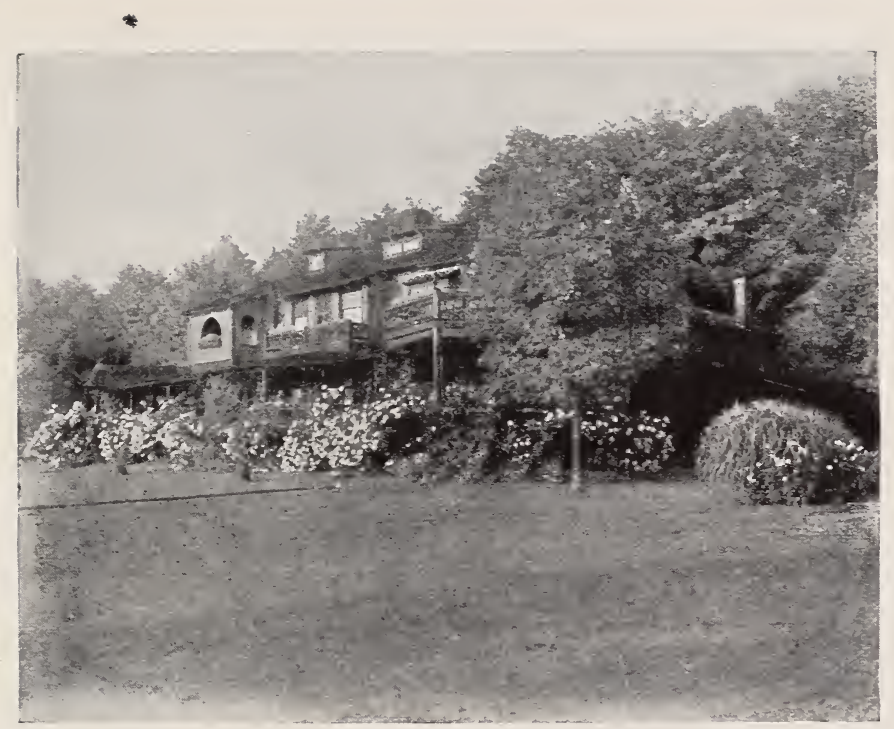

\section{Helps to a Beautiful Home}

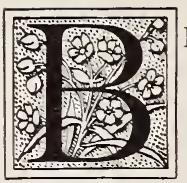

ELIEVING that our rapidly improving country is to become really beautiful as well as very great, and knowing that the unit of a beautiful country is the beautiful home, we have begun the growing of the trees, plants, shrubs and vines best adapted for home planting.

We are not particularly interested in great fruit farms and the like, but we are tremendously interested in home grounds of whatever extent, which usually include the plants and trees best adapted to give continuous pleasure and benefit to the home keepers.

We have had in preparation for some time an elaborate Catalogue. This Catalogue is intended to show in the best way yet shown the best growing things known in America. Its cover will breathe of the beautiful outdoor bloom-time of June, and each page will present a home necessity in plant or tree, shrub or vine.

Our plans for this Catalogue have grown upon us, and the mechanical work required has taken so much longer than expected, that we have been unable to have it ready for the spring of 1907 .

We have therefore prepared this little book of home helps. It represents exactly the same well-grown trees and plants, but it has one advan- 
tage which will not be possessed by the larger Catalogue: it offers the stock at much lower prices. As the larger and more elaborate Catalogue is not yet ready, we have not had to expend the money for it ; and what we are saving in delaying its issue for a season our customers are saving in the prices herein presented.

We do not wish to have the impression prevail that because the descriptions herein given are short and condensed, and the prices at which these excellent things are offered are low, that the stock we sell is anything less than the very best. On the contrary, it is of the first quality, and we base our claims for the business we expect to get upon he service we are prepared to give.

\section{Our Location an Ideal One}

Located in the heart of the southern Alleghany mountains, our nurseries are admirably situated-our clımate is just about the same as that of the Great Lakes latitude. The stock we grow is equally as hardy, therefore, as that produced anywhere in the eastern half of the United States.

The soil and climate of our southern mountains is such that many trees and shrubs grow more luxuriantly here than anywhere else. This is especially true of lawn trees and evergreen shrubs. IV'ith proper soil conditions and location as regards exposure, the native American plants indigenous to the southern Alleghanies will be found hardy as far north as the latitude of Quebec.

\section{Just a Few Words About Ordering}

Please order promptly. You cannot be too early, and you can be too late!

Let us have your name and address plainly written upon your order, in every case giving post-office, county and state, and the name of your nearest express office.

We prefer to ship by express whenever possible. Our stock enjoys a twenty per cent reduction from the regular merchandise rate. Please let us have plain and accurate directions for shipping.

Our prices are very low, and they are based on cash with the order. Money can be remitted by post-office or express money orders, or by draft on Knoxville or on New York.

PETER'S NURSERY COMPANY 


\section{Trees for the Home Grounds}

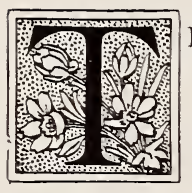

HE following list presents the best American trees, of proved hardiness and beauty, and certain to succeed if properly planted. All trees should be planted in fertile ground. It is safe to assume that if the ground would grow a good crop of corn or potatoes it would grow good trees, and it is just as sure that barren, rocky ground, or an ash heap, will keep trees from doing their best. Where trees must be planted along streets that have beengraded, with all the top soil removed, or where they are set about the home grounds with no fertile soil, a large hole should be dug and filled in with rich ground, old sods, bones, or the like, a little well-rotted manure being added. If the rich ground used is such as you would find in a good garden, no manure is necessary.

In $\mathrm{planting}$ these trees please remember that in digging the roots are necessarily cut somewhat.

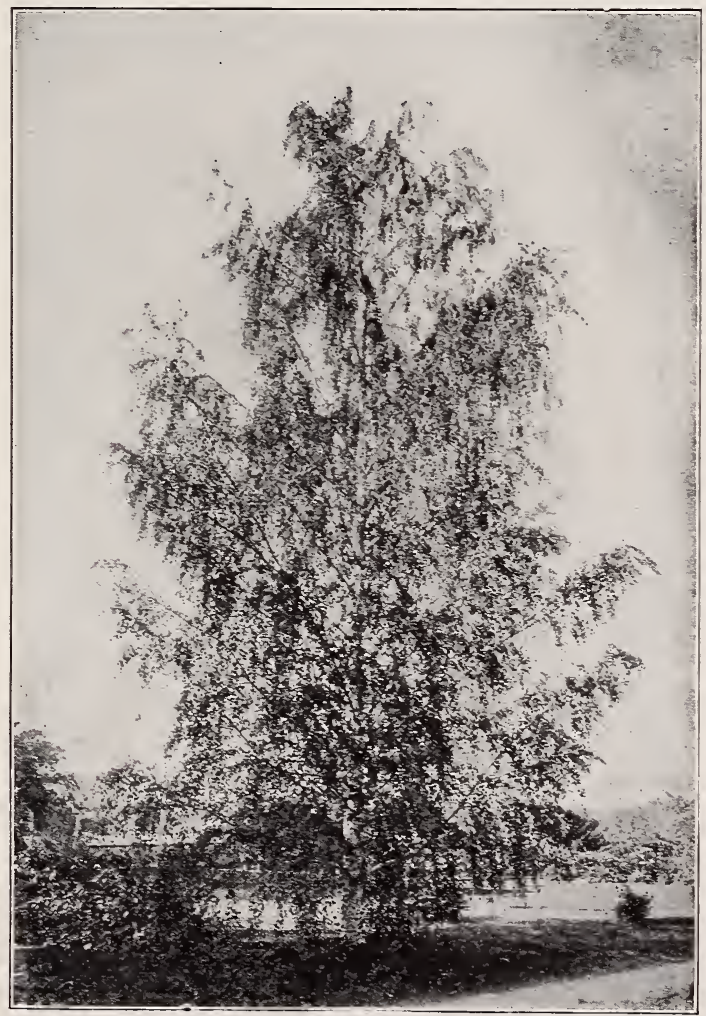

Cut-leaved Weeping Birch see page( 4) 


\section{Peter's Nursery Go., Knoxille, Tenn}

Trim them off sharply wherever mutilated. Trim the tops in a corresponding manner, and always plant a substantial stake beside the tree to protect it the first season or two. This stake can be fastened to the tree by passing an old leather strap or a piece of split rubber hose around the tree, crossing the ends between the tree and the stake, and then nailing these ends on the other side of the stake.

Newly set trees are benefited by protecting the ground with a mulch of loose material, or by keeping the ground constantly stirred, so that it does not bake or dry out injuriously.

\section{Ash, White (Fraxinus Americana)}

A rapid-growing tree, reaching 50 to 60 feet when mature. It is longlived, attains fine proportions, and is suitable for both lawns and streets.

8 to ro ft. . . . . . . . . 5o cts. each, $\$ 5$ per doz., $\$ 30$ per roo

\section{Beech, American (Fagus ferruginea)}

One of the finest American natives, reaching eventually a height of 60 feet ; are pyramidal in habit, and most suitable to extensive grounds.

5 to $6 \mathrm{ft}$. . . . . . . 75 cts. each, $\$ 7.50$ per doz., $\$ 45$ per roo

\section{Birch, European White (Betula alba)}

A rapid-growing tree, reaching 30 to 40 feet in height, and desirable because of its beautiful foliage and white bark. Does well on streets.

6 to $8 \mathrm{ft}$. . . . . . . 75 cts. each, $\$ 7.50$ per doz., $\$ 45$ per roo

\section{Birch, Cut-Leaf Weeping (Betula alba pendula laciniata)}

One of the finest lawn trees known. When young its habit is most graceful, and when it reaches its mature height of about 30 feet the long, slender branches droop attractively. The foliage is clean, fine in color, and beautifully cut; the bark is white.

4 to $6 \mathrm{ft} . \ldots \ldots \ldots \ldots$. . . . 50 cts. each, $\$ 5$ per doz., $\$ 30$ per 100

\section{Birch, Cherry, Sweet, or Black (Betula lenta)}

Grows to a height of 60 feet, and is satisfactory for planting in low and somewhat damp ground. Not adapted to street use. Has dark brown bark.

4 to $6 \mathrm{ft} . \ldots \ldots \ldots$. . . . . 50 cts. each, $\$ 5$ per doz., $\$ 30$ per Ioo

\section{Cypress, Deciduous (Taxodium distichum)}

A most attractive tree, apparently an evergreen, but losing its foliage every winter. The foliage is feathered, and the tree is of rapid, pleasing, pyramidal growth.

$3 \mathrm{ft} . \ldots \ldots \ldots$. . . . 50 cts. each, $\$ 5$ per doz., $\$ 30$ per roo 


\section{Chestnut, American (Castanea Americana)}

The American Sweet Chestnut is one of our most magnificent trees for ornamental uses, as well as for its delicious fruit. It grows rapidly, is adapted to large grounds or to be planted on wide streets, and is extremely desirable. It has been neglected as an ornamental tree because of its usefulness.

3 to $4 \mathrm{ft}$. . ....... 25 cts. each, $\$ 2$ per doz., $\$ 12.50$ per 100

\section{Dogwood, White (Cornus florida)}

A beautiful native tree, especially pleasing for the home grounds, as it grows from Io to 20 feet only; spreads widely, and is covered early in spring by large and showy white flowers, followed in the fall by beautiful red berries. Is being largely planted as its merits are recognized.

3 to $4 \mathrm{ft}$. . . . . . . $25 \mathrm{cts}$. each, $\$ 2.50$ per doz., $\$ 15$ per 100

\section{Elm, American (Ulmus Americana)}

A stately and magnificent American tree, adaptable to any use and almost any location if proper room is given. The Elm.shaded streets of New England are famous, and no tree is more comfortable or pleasant about the habitations of man.

5 to $6 \mathrm{ft}$. . . . . . . . 5o cts. each, $\$ 5$ per doz., $\$ 30$ per roo

\section{Ginkgo, or Maidenhair Tree (Salisburia adiantifolia)}

A Japanese tree that has proved to be hardy and altogether desirable in America. Its distinct leaves resemble those of the maidenhair fern. The tree grows rapidly, has no insect enemies, fornis a fine columnar object on the street or the lawn, and is of a most desirable character.

$6 \mathrm{ft} . \ldots \ldots \ldots \ldots$. . . . . 50 cts. each, $\$ 5$ per doz., $\$ 30$ per roo

\section{Laburnum. Golden Chain (Laburnum vulgare, or Cytisus Laburnum)}

A delightful lawn tree, sometimes known as Golden Chain because in spring its lony racemes of yellow flowers justify that name. Growing I 5 to 20 feet high, it is well adapted to lawn or home uses.

$3 \mathrm{ft} . \ldots \ldots \ldots \ldots$. . . . . 50 ts. each, $\$ 5$ per doz., $\$ 30$ per 100

\section{Maple, Sugar, Rock, or Hard (Acer saccharum)}

A most useful American tree, adaptable to street, park and lawn planting, and forming when young a beautiful pyramidal object, growing into stateliness with age. It is a deep-rooted, strong-growing, solid and substantial. tree, thriving everywhere except in a boggy location. The leaves assume a wonderfully rich autumn color.

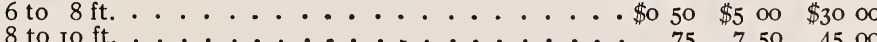

8 to 10 ft. .................... 757504500

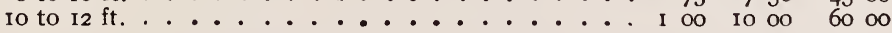




\section{Maple, Norway (Acer platanoides)}

A tree having rich green leaves and a beautiful round head as it attains size and age. Of reasonably rapid growth, and largely planted, with great satisfaction, on the street where a spreading tree is desirable.

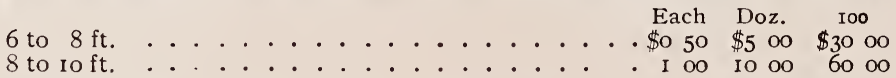

\section{Maple, Silver (Acer saccharinum)}

Especially desirable where extreme rapidity of growth is required. If given room to develop it forms a beautiful ornamental tree; but it is not suited to close planting on narrow streets. It is a much better tree than the Carolina poplar.

Each Doz. Ioo

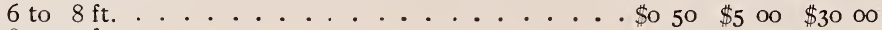

8 to ro ft. ................. 757504500

Io to I $2 \mathrm{ft} \ldots \ldots \ldots \ldots \ldots$ I

Mulberry, Teas' Weeping (SCorus alba, var. Tatarica pendula)

A dainty little lawn tree, growing to about the height of a man, and having interestingly cut foliage, on graceful branches which droop to the ground.

$5 \mathrm{ft} \ldots \ldots \ldots \ldots \ldots$. $\ldots \ldots$ each, $\$$ lo per doz., $\$ 60$ per 100

\section{Oak, Mossy Cup, or Burr (2uercus macrocarpa)}

A notable member of a magnificent family, making a massive open tree eventually, and growing more rapidly if properly planted than is usually supposed. Should be pruned severely when planted, and will then make desirable growth.

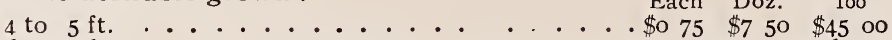

6 to $8 \mathrm{ft} . \ldots \ldots \ldots \ldots$. . . . . . . Io oo 60 oo

8 to Io ft. . . . . . . . . . I 50 I5 009000

\section{Poplar, Balsam (Populus balsamifera)}

A rapid-growing tree with aromatic buds in the spring, and suitable for large open spaces, in which it will reach a height of about 30 feet.

Io to $12 \mathrm{ft} . \ldots \ldots \ldots \ldots$. . . . $\$$ I each, $\$$ Io per doz., $\$ 60$ per 100

\section{Poplar, Carolina (Populus deltoides, var. Carolinensis)}

The all too-familiar street tree, which, while satisfactory where it is suited, is by no means proper for universal planting. If it is given room it makes a shapely and handsome tree very quickly, and there are streets in Washington which show the Carolina Poplar to great advantage.

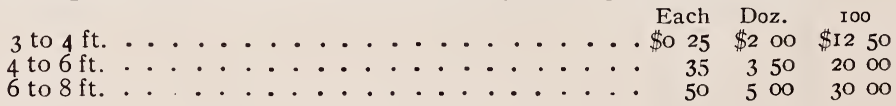




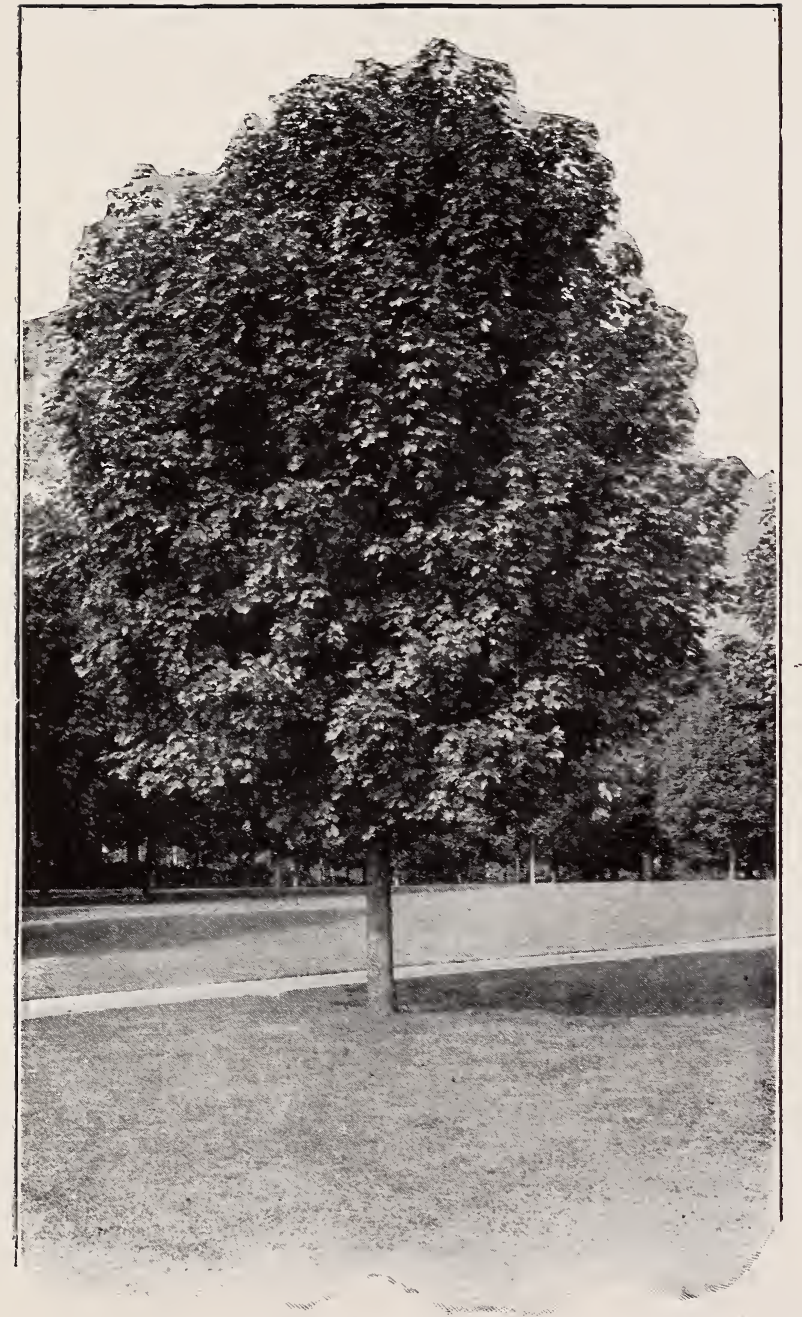

Norway Maple (see page 6) 


\section{Peter's Nursery Go., Knoxille, Tenn.}

\section{Poplar, Lombardy (Populus nigra, var. fastigiata)}

This has been called the exclamation point of the landscape-gardener. It is of upright and columnar habit, and is a desirable ornamental to the home grounds if properly placed.

6 to $8 \mathrm{ft}$.

Each Doz. I00

8 to ro $\mathrm{ft}$.

\$o $25 \quad \$ 200 \quad \$ 12 \quad 50$

$50 \quad 350 \quad 2000$

\section{Plum, Purple-leaved (Prunus Pissardi)}

A beautiful foreign tree which has proved to be the best of our purple-leaf introductions. It holds rich amber-red foliage until late in the fall. The flowers are white and pink in the spring, and are in delightful contrast to the deep amber-red branches. The tree is very desirable for giving distinct color to groups of other trees.

4 to $5 \mathrm{ft}$ Each Doz. 100

to $6 \mathrm{ft} \ldots \ldots \ldots 025250 \quad \$ 1500$

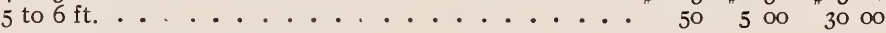

\section{Red Bud, or Judas Tree (Cercis Canadensis)}

A particularly pleasing ornamental tree, reaching a height of 20 feet, and forming a round head. In the spring, before the leaves are developed, the branches are literally covered with delicate deep pink flowers. The Red Bud is fine to plant with Dogwood.

Each Doz. $\quad$ 100

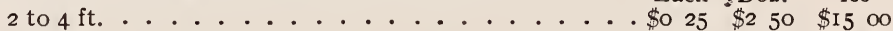

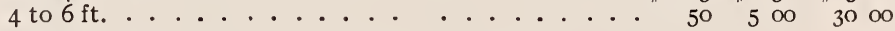

\section{Sweet Gum (Liquidambar styraciflua)}

A medium-sized native tree of extreme beauty. It becomes roundheaded, or sometimes tapering. The leaves are star-shaped, and a beautiful glossy green, as if varnished, during the summer, turning to deep purple or crimson in fall. The fruit hangs from the branches in a most attractive way. One of the best trees for street or lawn planting.

6 to $8 \mathrm{ft} . \ldots \ldots \ldots . \ldots 75$ cts. each, $\$ 6$ per doz., $\$ 40$ per Ioo

\section{Sycamore, or Oriental Plane (Platanus orientalis)}

A notable tree of very rapid growth, reaching a height of 50 to 70 feet, and forming a most striking object as it becomes old, if afforded room. It is also most satisfactory as a street tree.

6 to $8 \mathrm{ft}$. . . . . . . . 50 cts. each, $\$ 5$ per doz., $\$ 30$ per 100

\section{Tulip, or Yellow Poplar (Liriodendron tulipifera)}

While this is one of the best of our forest trees, it is also one of the most adaptable trees for streets or lawns. It grows rapidly, is of fine and somewhat rounded form, has clean and handsome bark, rich and distinct leaves, exquisite magnolia-like flowers in June. Each Doz. Ioo 6 to $8 \mathrm{ft} \ldots \ldots \ldots \ldots \ldots$............ 50 50 $\$ 5$ oo $\$ 3000$ 8 to ro $\mathrm{ft.} \ldots \ldots \ldots \ldots 75750 \ldots 4500$ Io to $12 \mathrm{ft} . \ldots \ldots \ldots \ldots$. . . . . . . . . I5 00 


\section{Helps to a Beautiful Home}

\section{Shrubs for the Home Grounds}

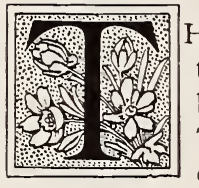

HIS class includes the shrubs that lose their leaves in the winter-properly called deciduous shrubs. These are best planted close by the home or in clumps on the lawn. They do best, as may well be supposed, in ground of good quality. The modern method is to plant a number of contrasting shrubs in one group, so planning as to secure a succession of bloom and of color in the foliage and fruit. All the shrubs we present are of suitable character for home use, and of decided merit. Their special qualities are mentioned in connection with the descriptions.

\section{Althea. Rose of Sharon (Hibiscus Syriacus)}

A shrub of free-flowering habit, and particularly useful because it may be trimmed into shape, serving well as a hedge plant or as a developing, blooming shrub. Its flowers are produced late in the season, and are large and handsome, in various colors, both single and double.

2 to $3 \mathrm{ft}$.............. $25 \mathrm{cts}$. each, \$2 per doz., \$12.50 per Ioo

\section{Azalea, Chinese (Azalea mollis)}

A plant from China, having light green leaves and flowers of the most striking and attractive character, appearing in bunches on the ends of the shoots, and making the plants a perfect blaze of color. Seldom grows over 3 feet in height, and blooms about the middle of May.

2 to $3 \mathrm{ft}$.............. $\$$ I each, $\$ 8$ per doz., $\$ 60$ per roo

\section{Barberry, Thunberg's Japanese (Berberis Thunbergii)}

A most beautiful shrub, suitable either for hedging or for lawn planting. It is of compact growth, from 2 to 3 feet in height, and the branches droop gracefully to the ground. The foliage is particularly pleasing in early spring, with its various shades of light green, turning in the fall to a brilliant crimson, not half so bright, however, as the scarlet berries which fairly cover the drooping branches. Having defensive thorns, this plant is good for hedges, and will take care of itself.

$\mathrm{I} / 2$ to $2 \mathrm{ft}$ Each Doz. 100

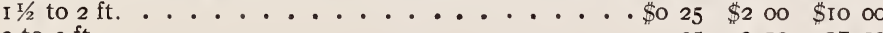

2 to $3 \mathrm{ft} . \ldots \ldots \ldots \ldots{ }_{35}{ }_{2}{ }_{50}{ }_{17} 50$

\section{Barberry, Purple (Berberis vulgaris, var. purpurea)}

This form of the Barberry has violet-purple foliage and fruit, and grows somewhat taller than Thunberg's barberry. It is effective in masses or groups, particularly.

Each Doz. $\quad 100$

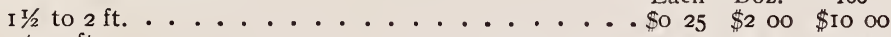

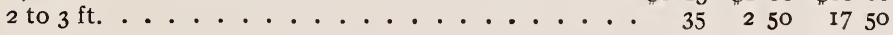




\section{Buckberry (Gaylussacia ursina)}

Shrub 3 to 6 feet high, with spreading branches, white or pinkish flowers, and abundant clustered fruit late in summer. The berries have a peculiar and pleasant acid flavor.

2 to $3 \mathrm{ft}$............ 50 cts. each, $\$ 5$ per doz., $\$ 30$ per roo

\section{Catalpa, Chinese (Catalpa Bungei)}

A form of the Catalpa having the characteristic large heart-shaped leaves, which form a low-spreading head. A very attractive lawn tree, reaching a height of 6 to Io feet; its distinct form and bright foliage make it conspicuous.

2 to $3 \mathrm{ft} . \ldots \ldots \ldots \ldots$. 50 cts. each, $\$ 5$ per doz., $\$ 30$ per roo

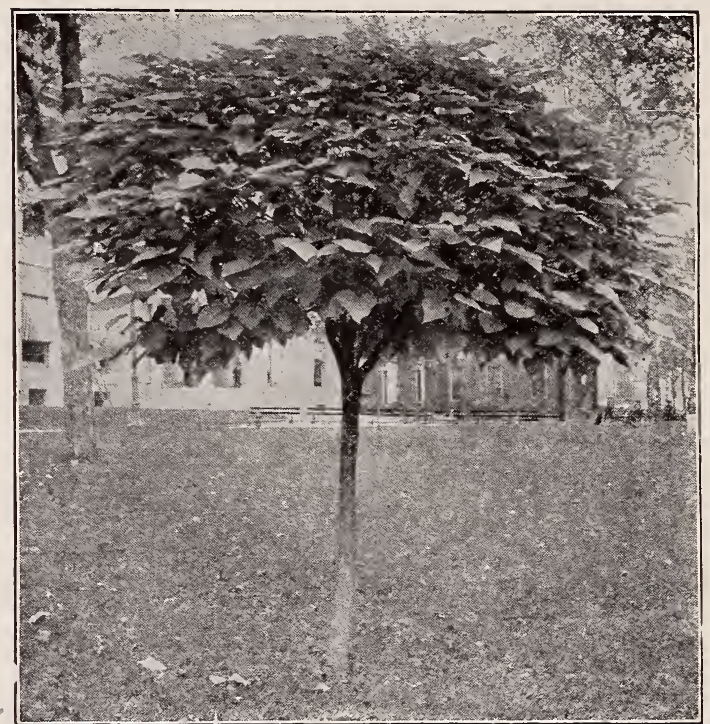

Chinese Catalpa

\section{Deutzia}

A class of invaluable plants introduced from Japan, including: flowers of white and pink, borne in May on plants of graceful character. D.gracilis, the earliest, is covered with pure white flowers. $D$. crenata has double flowers of a pinkish hue, coming several weeks later. Either form is desirable for the edge of the shrubbery border or to be planted close to the house.

I $1 / 2$ to $2 \mathrm{ft}$., 25 c.ea., $\$ 2.50$ per doz., $\$ 15$ per IoO.

\section{Elder, Golden (Sambucus nigra, var. aurea)}

A strong-growing shrub with golden foliage, attractive in contrast with green- and purple-leaved varieties. Has the usual showy flowers of the Elder in early summer. Is generally planted in shrubbery borders or: masses, to add color.

$\mathrm{I} 1 / 2$ to $2 \mathrm{ft} . \cdots 25 \mathrm{cts}$, each, $\$ 2.50$ per doz., $\$ 15$ per Ioo. 


\section{Helps to a Beautiful Home}

\section{Golden Bell (Forsythia viridissima)}

Blooms very early in spring, its long branches being covered with bright yellow flowers. 2 to $3 \mathrm{ft}$.......... $25 \mathrm{cts}$. each, $\$ 2$ per doz., $\$ 12.50$ per 100

\section{Hydrangea paniculata, var, grandiflora}

A shrub that has grown into great popularity and is widely planted. It produces large panicles of showy white flowers in July and August, which hang long on the plant. If given very rich soil, and plenty of water, it will make bloom heads of phenomenal size. It may be trained up as a standard, or kept in a low mass, and is efficient in any place.

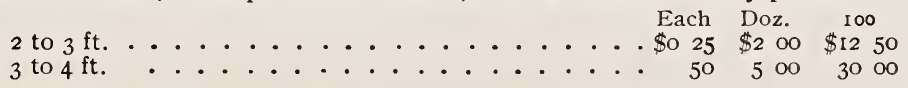

\section{Jasmine, Yellow (Jasminum nudiflorum)}

A somewhat tender plant, of an interesting character, having sweetscented yellow flowers in early spring.

Strong plants .......25 cts. each, \$2.50 per doz., \$15 per 100

\section{Lilac. Syringa}

It is hardly necessary to describe this, the most widely distributed and delightful of all the old-fashioned shrubs. To know the Lilac, however, one should see it where it is given an honored place, in the Arnold Arboretum, at Boston. Here, under vigorous cultivation, the great bushes of various varieties are an attraction for many weeks to thousands of people.

We name a few of the best varieties: $\mathbf{S}$. vulgaris, the old-fashioned sort; S. vulgaris, var. alba, the well-known single white; Charles $\mathbf{X}$, double purple, with reddish tint ; large flowers ; Madame Lemoine, beautiful double white flowers; Belle de Nancy, double white flowers, tinged with purple; Madame Casimir-Perier, the best double white variety;

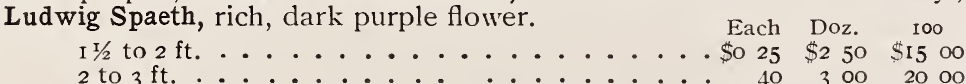

\section{Flowering Locust. Rose Acacia (Robinia hispida)}

A shrub or small tree, growing $S$ to ro feet in height. All parts of the plant except the flowers are covered with rather sticky hairs, or bristles. The flowers are deep rose-color in May, and are very attractive.

2 to $3 \mathrm{ft} . . . . . .25 \mathrm{cts}$. each, $\$ 2.50$ per doz., \$15 per Ioo

\section{Magnolia Stellata}

A most desirable form of a desirable family, covered in spring with its beautiful star-shaped white flowers, of large size. Growing 8 or ro feet in height, this Magnolia forms an object of extreme attractiveness in any garden, and it is the chief ornament of many a tasty home.

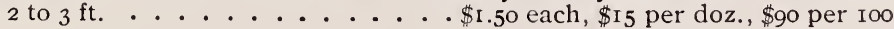




\section{Peter's Nursery Go, Knoxville, Tenn.}

\section{Mock Orange (Philadelphus coronarius)}

A sweet-scented old favorite, with its beautiful white flowers appearing in early June.

3 to $4 \mathrm{ft}$. . . . . . . 25 cts. each, $\$ 2.50$ per doz., $\$ 15$ per 100

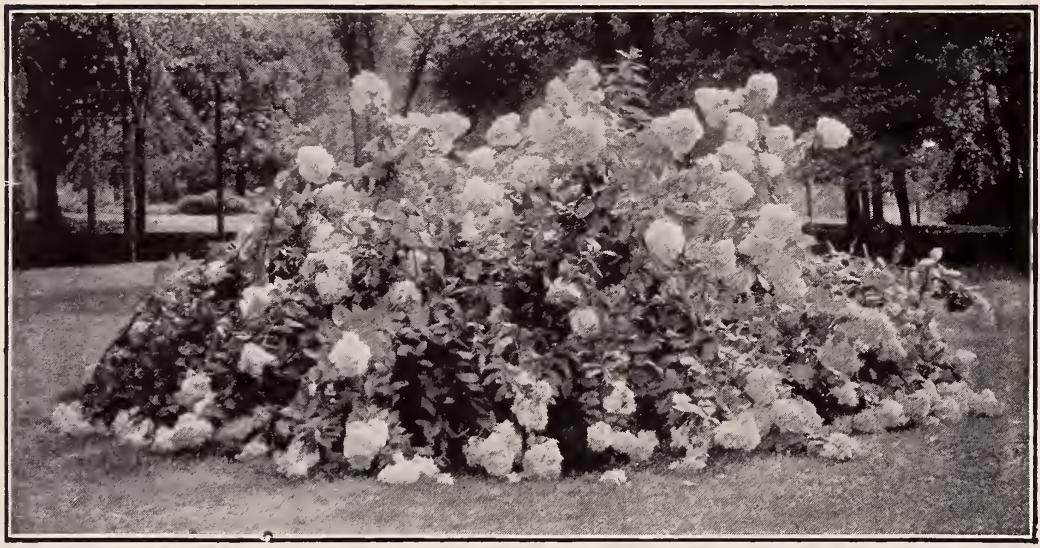

Hydrangea paniculata grandiflora (see page 10 )

\section{Privet (Ligustrum)}

Plants usually used for hedging, but making, nevertheless, beautiful columnar specimens on the lawn, if properly trimmed, and supplying sweetscented flowers in May. Ovalifolium, or California, Amoor River and Regel's are each satisfactory varieties, the Amoor River being evergreen.

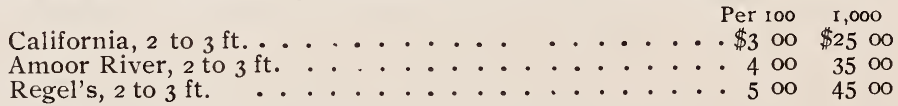

Snowball (Viburnum Opulus, var. sterile)

The common, well-known and always desirable garden favorite, of strong growth and upright habit.

Each Doz. 100

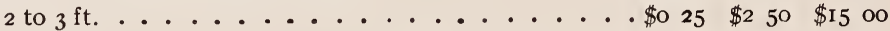

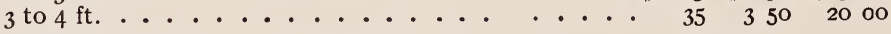

\section{Snowball, Japan (Viburnum tomentosum, var. plicatum)}

This is a more desirable form, of strong growth, and presenting a beautiful appearance even when out of bloom, while when its pure white round balls cover the plant it is a most attractive object.

2 to $3 \mathrm{ft}$. . . . . . . . 50 cts. each, $\$ 5$ per doz., $\$ 3$ o per roo 


\section{Snowball. Wayfaring Tree (Viburnum Lantana)}

A rapid-growing shrub with large foliage, turning bronze in the fall. The flowers are white, followed by red and black fruit in autumn.

2 to $3 \mathrm{ft}$. . . . . . . 25 cts. each, $\$ 2.50$ per doz., $\$ 15$ per 100

\section{Spiraea, Anthony Waterer (Spiraa Bumaldi, var. Anthony Waterer)}

The best of all the Spireas, bearing large panicles of rich pink flowers for many weeks in midsummer. Makes a beautiful hedge, or is fine as a single specimen.

I to $\mathrm{I} 1 / 2 \mathrm{ft} . \ldots \ldots \ldots \ldots$. . 20 cts. each, $\$ 2$ per doz., $\$ 10$ per 100

\section{Spiraea Van Houttei}

White flowers in delicate bunches, which cover the gracefully drooping branches. A single specimen of this plant may be grown to great beauty, or it forms an extremely handsome border in the shrubbery. I $1 / 2$ to $2 \mathrm{ft} . \ldots \ldots \ldots . . .25 \mathrm{cts}$. each, $\$ 2.50$ per doz., $\$ 15$ per 100

\section{Sweet-scented Shrub (Calycanthus floridus)}

An old favorite for its aromatic odor, especially developed in its deep chocolate-colored and very interesting flowers.

2 to $3 \mathrm{ft}$. . . . . . . 25 cts. each, $\$ 2.50$ per doz., $\$ 15$ per 100

Sumach (Rhus glabra, var. laciniata)

A cut-leaf form of the familiar Sumach, far more desirable than the common shrub of the woods. The leaves resemble large fern fronds, and the small flowers are followed by rich scarlet fruit in the fall.

2 to $3 \mathrm{ft} . \ldots . . .25 \mathrm{cts}$. each, $\$ 2.50$ per doz., \$15 per Ioo

\section{Tamarisk (Tamarix)}

Tall-growing shrubs with slender branches, seeming like evergreens when the leaves are first seen, but also most distinct before the leaves appear, by reason of the complete covering of small pink flowers.

3 to $4 \mathrm{ft}$. . . . . . . 25 cts. each, $\$ 2.50$ per doz., $\$ 15$ per 100

\section{Verbena Shrub. Blue Spirea (Caryopteris Mastacanthus)}

A small shrub bearing great quantities of rich blue flowers late in the season. Can be kept low, and is extremely distinct and fine.

$2 \mathrm{ft} . \ldots \ldots \ldots . . .25 \mathrm{cts}$. each, $\$ 2.50$ per doz., $\$ 15$ per 100

\section{Weigela (Diervilla)}

One of the best of the flowering shrubs because of its masses of white, pink and deep red flowers all through May. There are several varieties.

$2 \mathrm{ft} . \ldots \ldots \ldots . . .25 \mathrm{cts}$. each, $\$ 2.50$ per doz.. $\$ 15$ per 100 


\section{Evergreen Trees and Shrubs}

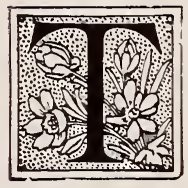

$\mathrm{HE}$ first impression of an evergreen in the mind of the casual reader is that the term refers only to pines or spruces, or some other of the coniferous evergreens; that is, the trees bearing cones and holding their foliage. In addition to the splendid cone-bearers, however, there are some superb trees and shrubs that hold their leaves throughout the winter, including one of the barberries, the boxwood, the superb American holly, and the less hardy but exquisitely beautiful great Magnolia of the South. The select list which follows mentions the best evergreen trees and shrubs for intimate home use. These serve to make the grounds cheerful in the winter, and ought to be planted with freedom.

\section{Arborvitae, American (Thuya occidentalis)}

A tree of slim growth, which eventually reaches a height of 30 to 40 feet, but is usually treated as a shrub or small tree. It makes a most excellent hedge or windbreak, and if it is trimmed it can be kept to any desired size. Its rich green foliage turns slightly bronzy in the cold weather.

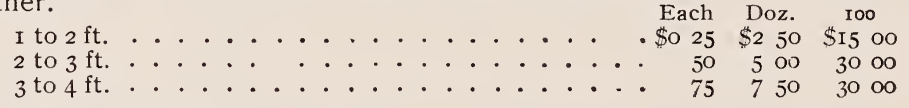

\section{Arborvitae, Golden Chinese (Thuya orientalis, var. aurea nana)}

Really, a golden ball results from the planting of a good specimen of this charming evergreen, which is of dwarf and compact habit, and of a rich yellow tone. It is fine not only when planted on the lawn, but in boxes or tubs, either in or outdoors. IWhile of free growth, it never reaches a great height, keeping well under five feet.

I to $\mathrm{I} / 2 \mathrm{ft} . \ldots \ldots \ldots$. . . . 50 cts. each, $\$ 5$ per doz., $\$ 30$ per Ioo

\section{Mahonia (Berberis Aquifolium)}

A very beautiful evergreen shrub, with broad leaves, somewhat distinctly resembling those of the holly and edged with strong spines. Bright green throughout the summer, this attractive foliage turns to a rich bronze in the fall. In April there are clear yellow flowers, which precede the beautiful light green of the young foliage, giving altogether a great range of striking color. The plant, which is of low growth, does well in shady spots. 


\section{Boxwood (Buxus)}

"Grandmother's garden" used to be dignified by the great Boxwood trees. Now fashion has again set the seal of approval upon them, and vast quantities are imported from Belgium and Holland because America has not been able to grow the trees rapidly enough to meet the demand. We have some splendid stock in various sizes, suitable either to plant for the delightful and fragrant hedge which the Boxwood makes, or to grow as single specimens, of a broad, rounded character, always cheerful and green with the glossy, small, abundant foliage. There is a dwarf variety which is useful for edging walks or driveways. We offer excellent plants at $\$ 5$ per 100 .
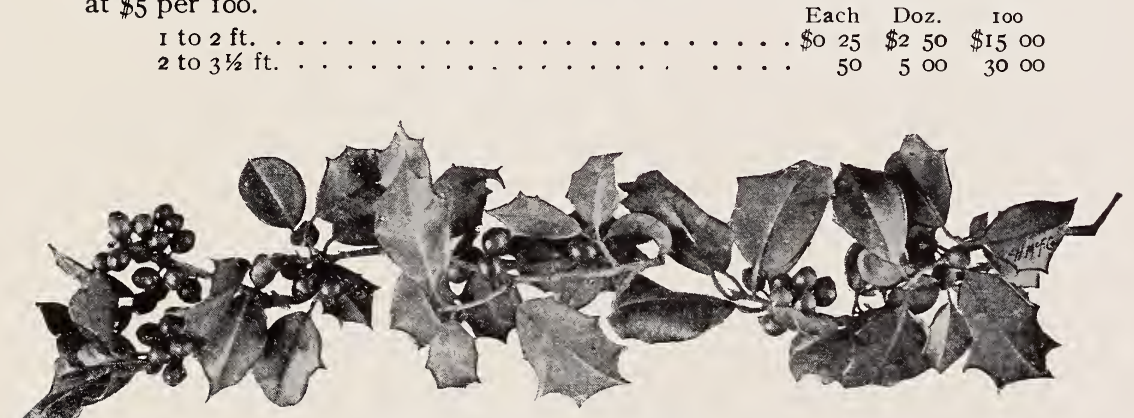

A branch of American Holly

\section{Holly, American (Ilex opaca)}

Vast quantities of the branches of the beautiful red-berried Holly are used for Christmas decorations. Few who thus add to holiday cheer realize that this, America's most beautiful evergreen, can be had the year round as a delightful home adornment. We have perhaps the best and largest stock of well-grown Holly plants in America, and our system of root-pruning and frequent transplanting permits them to be handled with very little risk. A fine, well-grown Holly plant in the home grounds will provide a continuous bouquet of its beautiful scarlet berries all through the winter, and no florist can give you anything half so cheerful or attractive. In planting, all the leaves should be removed and the branches sharply pruned back. Trimming does not hurt the trees, which are naturally of a bushy growth. By all means, make your home unique as well as beautiful with a few of these delightful Holly trees. Although rather expensive for a hedge, they do make a most attractive and substantial division line. The leaves are somewhat thorny, and, as they are closely set, nothing can get through. Please note that our stock of Holly trees is the finest in America.

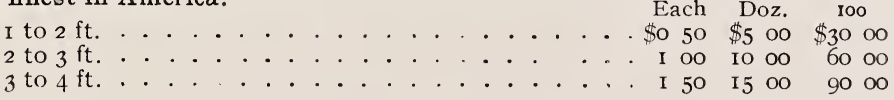




\section{Juniper, Irish (Juniperus communis, var. Hibernica)}

An evergreen of distinctly conical habit, making in fact a pillar of green. The foliage is very delicate, but the plant is sturdy and strong, growing eventually to a height of Io feet. It is one of the most distinct of the class.

Each Doz. 100

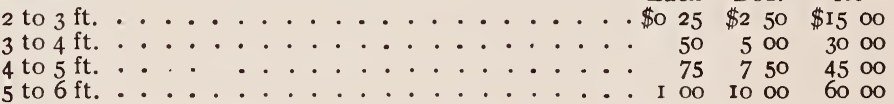

\section{Juniper, Prostrate, or Trailing (Juniperus Sabina, var. prostrata)}

A mass of rich, delicate green foliage is formed right on the surface of the ground by this peculiar and very interesting plant. We have seen it used most successfully for bedding, forming a mat, or mass of green in front of larger evergreens.

I $1 / 2$ to $2 \mathrm{ft} . \ldots \ldots \ldots \ldots \ldots$. $\$ 1.50$ each, $\$ 15$ per doz., $\$ 90$ per 100

\section{Pine, White (Pinus Strobus)}

It is interesting to note that even we neglectful Americans are coming to realize that the White Pine is one of the finest ornamental trees, in addition to being an extremely valuable timber tree. It is of upright growth and most beautiful appearance, the color of the needles giving it great distinction.

2 to $3 \mathrm{ft}$. . . . . . . 5 50 cts. each, $\$ 5$ per doz., $\$ 30$ per Ioo

\section{Cypress, Golden Japan (Retinospora plumosa aurea)}

This has foliage of the delicacy of seaweed, but of a bright golden hue. In extremely exposed locations it sometimes winter-kills at the ends of the branches. It is an excellent evergreen to plant in tubs or large pots for foliage decoration in the winter season, and is also capable of being grown to very satisfactory specimen shape in the home grounds. It reaches a height of 6 to ro feet under ordinary conditions.

2 to $3 \mathrm{ft} . \ldots \ldots \ldots \ldots$. $\$$ I.50 each, $\$ 15$ per doz., $\$ 90$ per 100

\section{Magnolia grandiflora}

The northern tourist who is fortunate enough to see the great-flowered Magnolia in bloom in the South for the first time experiences a new pleasure in life. Yet, if it never gave forth its fragrant, rich, creamy flowers of great size, it would be one of the most valuable of our trees because of its broad, glossy and handsome foliage, retained the year round. As a single specimen tree about the home, or for larger grounds to border an avenue, nothing is finer. It is not hardy north of Washington, though there are specimens which have endured the winters in 
Philadelphia, or even farther north. The tree will reach in time a height of 30 feet or more, and it is beautiful at all seasons and stages. See illustration of the foliage on back cover of this Catalogue.

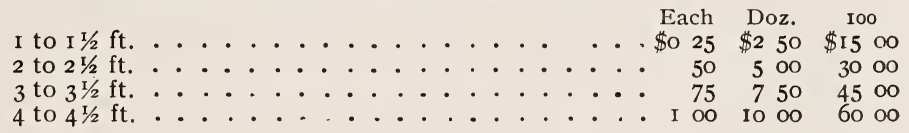

\section{Spruce, Norway (Picea excelsa)}

A fit companion for the White Pine is this Spruce, which, while young, is of conical and symmetrical habit, and when old assumes a gracefully informal and sometimes drooping shape. It is invaluable not only as a single specimen about the home grounds, but is one of the very best for screens or windbreaks. It may be planted closely and trimmed so as to make a solid wall of green the year round.

2 to $3 \mathrm{ft}$. . . . . . . . 5 cts. each, $\$ 5$ per doz., $\$ 30$ per roo

\section{Spruce, Hemlock (Tsuga Canadensis)}

Surely a wonder is this Spruce, which forms one of the great American forest trees, reaching more than Ioo feet in height and a diameter of four feet and more in the course of years. Most people know it, however, as the most graceful of the smaller evergreen trees. Its form is its own, and, while it is slow of growth as a tree, it develops rapidly in the shrub form. A single specimen is handsome, and a hedge so treated as to allow the plumy tops to stand untrimmed, is one of the finest things imaginable.

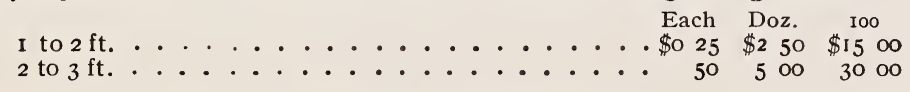

\section{Spruce, Colorado Blue (Picea pungens, var. glauca)}

From the far West comes this peculiarly bluish evergreen, of most pleasing habit and a distinct conical form. Our plants are of the best and bluest color. One good specimen in a group of evergreens adds a distinct and most attractive element of color, and we commend our selected and really blue specimens, much superior to unselected seedlings, to those who want the full effect of this unique conifer.

2 to $3 \mathrm{ft} . \ldots \ldots \ldots \ldots \ldots$. $\$ 2$ each, $\$ 20$ per doz., $\$ 150$ per roo

\section{Yucca filamentosa. Spanish Bayonet}

Particularly well known and largely grown in the South, its leaves resembling slightly the century plant. It has a branching habit, and its creamy bells produce a stately sight when they crown the odd-looking plant in luxuriant profusion.

I to $\mathrm{I} 1 / 2 \mathrm{ft} . \ldots \ldots \ldots \ldots . . .25 \mathrm{cts}$. each, $\$ 2$ per doz., $\$ 15$ per 100 


\section{Climbing and Trailing Vines}

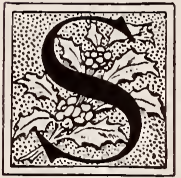

URELY nothing helps to make the home beautiful more than well-selected vines. Many an inconspicuous or really ugly dwelling has been made a thing of beauty by a covering of Boston Ivy or some other rapidly growing vine. Banks, large stones, and many other objects which it is desirable to conceal can be screened in beauty by the trailing vines. We commend them to our friends as of the utmost value for home adornment, and we call particular attention to the fact that vines do not require an extended space in which to flourish. A square foot of otherwise unavailable ground will give foundation for a beautiful wistaria, and a single post in the back yard may be made to support a clematis which will be a thing of glory in its blooming time.

\section{Akebia quinata}

This Japanese ine is not nearly so well known as it ought to be. It has most interesting and individual five-fingered foliage, almost evergreen. It grows rapidly, has attractive flowers, and is altogether a most pleasing vine.

Strong plants ........... 20 cts. each, $\$ 2$ per doz.

\section{CLEMATIS}

In planting Clematis, don't make the mistake of trying to train them on wire or strings. They need a firm support which will prevent them from being bent and twisted and their ends whipped by the wind. This often results in cracking the outer covering of the stems, causing the plants to lose their strength and vitality.

C. Jackmani is a twining vine, with, in this variety, broad, velvety, purple flowers of four to six sepals and a ribbed bar down the center of each.

Strong plants ........... . . 40 cts. each. \$4 per doz.

C. Henryi. Much like Jackmani, except that the flowers are a beautiful creamy white. The plant is robust and a very free bloomer, being covered in its season with a mass of flowers that hide the vine and its support.

Strong plants ........... . $40 \mathrm{cts}$. each, $\$ 4$ per doz.

c. paniculata. The small-flowered sort, blooming later than the others, and bearing a wealth of small white flowers of delightful fragrance, remaining in full beauty several weeks. The foliage is thick and heavy and forms one of the best-known coverings for porches. The most vigorous climber of the lot.

Strong plants ......... $25 \mathrm{cts}$. each, $\$ 2.50$ per doz. 


\section{Dutchman's Pipe (Aristolochia Sipho)}

Broad, heart-shaped leaves, produced on a strong-growing stem, characterize this attractive vine, which has the further interest given it by curious green Howers, shaped like a pipe. It needs plenty of rich soil to develop the full strength.

Strong plants ......... 50 cts. each, $\$ 5$ per doz.

\section{Euonymus radicans, var. variegata}

Not of very rapid growth, but of the most distinct character is this climber, especially adapted to covering stone walls. The leaves are so variegated as to look like flowers, and they stand bright winter sunshine as well as the hardship of cold winds.

Strong plants, $25 \mathrm{cts}$. each, \$2.50 per doz., \$15 per Ioo

\section{Honeysuckle}

\section{(Lonicera Periclymenum)}

The common evergreen Honeysuckle has not only to commend it its almost evergreen foliage and its sweet and beautiful flowers, but its habit of holding steep banks. To one who has not tried it there will come a revelation of beauty in setting along roadsides a few plants of the Honeysuckle, which will

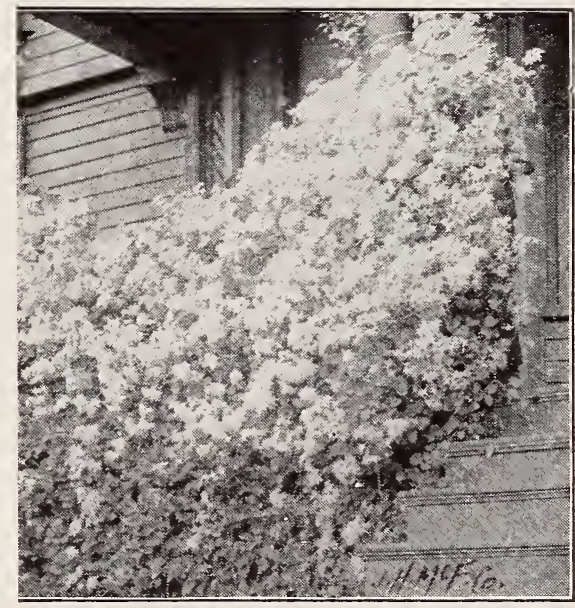

Clematis paniculata (see page 18 ) there establish, grow rapidly and keep the banks from washing.

Strong plants ........... Io cts. each, \$I per doz.

\section{Honeysuckle, Japan Everblooming (Lonicera Halleana)}

This delightful vine, with its white and yellow flowers, blooms more frequently than the common sort, having several successive crops.

Strong plants . . . . . . . $25 \mathrm{cts}$. each, $\$ 2.50$ per doz.

\section{Ivy, Boston, or Japanese (Ampelopsis tricuspidata)}

Probably the most useful vine now extant for covering walls of any material. Its growth seems delicate, and yet is rapid and strong, and as it acquires age its glossy leaves cover any surface with a curiously symmetrical effect. In the fall the leaves assume gorgeous tints of scarlet and yellow, and the closely matting stems are a protection to any wall.

Strong plants ....... I5 cts. each, \$1.25 per doz., \$1o per Ioo 


\section{Peter's Nursery Go., Kñoxille, Tenn}

\section{Ivy, English (Hedera Helix)}

This old favorite is hardy except in the far North, and is evergreen. Its deep green leaves, white-veined, are most attractive.

Strong plants . . . . . . I5 cts. each, $\$ 1$.25 per doz., $\$$ Io per Ioo

\section{Matrimony Vine (Lycium Chinense)}

Another vine especially pleasing on a bank or over a wall. It has delicate foliage, masses of interesting pink flowers, and, later on, great clusters of crimson berries. It can also be trained on an upright, where it is very effective.

Strong plants ....... 25 cts. each, $\$ 2.50$ per doz., $\$ 20$ per Ioo

\section{Trumpet Vine (Bignonia radicans)}

The gorgeous orange and scarlet flowers, together with the rich and varied foliage of this splendid plant, commend it to any one who once sees it. It will grow to a considerable height, and is rapid and hardy.

Strong plants . . . . . 25 cts. each, $\$ 2.50$ per doz., $\$ 20$ per roo

\section{Vinca major, var. variegata}

A trailing vine having foliage of white and green, and beautiful blue flowers. Forms a very pleasing bed or mass if allowed to grow freely.

Strong plants ......... $25 \mathrm{cts}$. each, $\$ 2.50$ per doz.

\section{Virginia Creeper. Woodbine (Ampelopsis quinquefolia)}

The native form, and one of the best of all strong-growing climbing vines, though it does not cling so well as the Boston Ivy. In fall the foliage assumes rich colors.

Strong plants .......... I5 cts. each, \$1 50 per doz.

\section{WISTARIA}

Chinensis. If you have ever been in Japan, that home of the most artistic race in the world, and where the gardeners grow things in a way that is the despair of western people, we know that you have been struck with the prevalence of the Wistaria. A Japanese laborer will build a little one-story house, with paper partitions and paper windows, and around its eaves he will train a Wistaria-just the kind of Wistaria we offer-with long, pendulous racemes of delicate, light purple, pea-shaped flowers and graceful pale green foliage.

Chinensis alba. The white variety, in all respects the same as the purple, except in color.

Multijuga (Japan Wistaria). A noble variety, with racemes of flowers often two to three feet long. A trifle later than the other varieties.

25 cts. each, $\$ 2.50$ per doz. We have a fine lot of plants at $50 \mathrm{cts}$. each, or $\$ 5$ per doz., and a few large imported plants, fully 5 feet high, at $\$ 1$ each. If you wish quick effect, the $\$ 1$ plants are the cheaper. 


\section{Helps to a Beautiful Home}

\section{Hardy Herbaceous Plants}

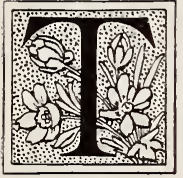

HESE plants are particularly characteristic of the oldfashioned garden, of which most of us think with longing if we have not had the good fortune to have acted with wisdom and thus to have provided ourselves with these charming growths of an earlier age. It is to the herbaceous border, which, being interpreted, means that part of the garden in which grow the plants coming up each spring of themselves, going through their appointed season of attractive-bloom, and then dying down and apparently disappearing cleanly over the winter, that we must turn for the most brilliant and pleasing of our familiar garden flowers. For many years flower-lovers overlooked these old favorites and devoted attention to the tender plants, requiring to be wintered in a greenhouse or indoors, and producing during the summer blooms of great uniformity and monotony. Using herbaceous plants we may have brave white flowers to vie with the last snow in purity, and in acceded beauty, followed by a continual procession of dainty and rich, gorgeous and delicate flowers, until the hardy Chrysanthemums defy the first frosts. The herbaceous garden takes but little care if it is given at first planting deep, rich and suitable soil, and even neglect will not entirely damp its beauties.

In preparing for the hardy herbaceous border, or for a bed of these delightful old-fashioned or new-fashioned, and altogether desirable plants, it is well to see that the soil is dug up to a depth of at least 18 inches, and that it is made rich without being rank, through the use of manure that is not fully rotted. Good drainage is essential, and that is provided by deep digging and by incorporating into the soil well-rotted but loose manure, rotted leaves and a light and fertile wood soil, often known as leaf-mold. Let no ambitious flower-lover, however, be discouraged at the absence of the very best possible material in preparing a little corner of hardy plants of this nature. Simply get the best soil you can, and stick in a plant. You will get some bloom to reward you, and better bloom if you can do better by the plant.

The list we present is selected in every way, and everything in it will give you efficient service in the garden. Our stock is large and well grown, and the surprising prices we present are only made possible by fortunate circumstances in growth and handling. We expect to obtain the good will of thousands of people who become acquainted with us through obtaining from this selection hardy herbaceous plants. 


\section{$\underbrace{\text { Ptarmica flore pleno, "The Pearl" }}_{\text {Peter's Nursery Go., Knoxville, Te }}$}

Produces double white flowers in summer and fall, and is very attractive in connection with other plants of the same character or those to which its average height of about 15 inches will be suitable.

\section{Bocconia cordata}

This is also known as Plume Poppy. It grows to a height of 4 to 6 feet, bearing spikes of white flowers in connection with large and rich tropical-looking foliage.

\section{Anemone Japonica, var. Queen Charlotte. Windflower}

One of the most delightful of the hardy herbaceous plants because it provides from September until frost a constant succession of large, semi-

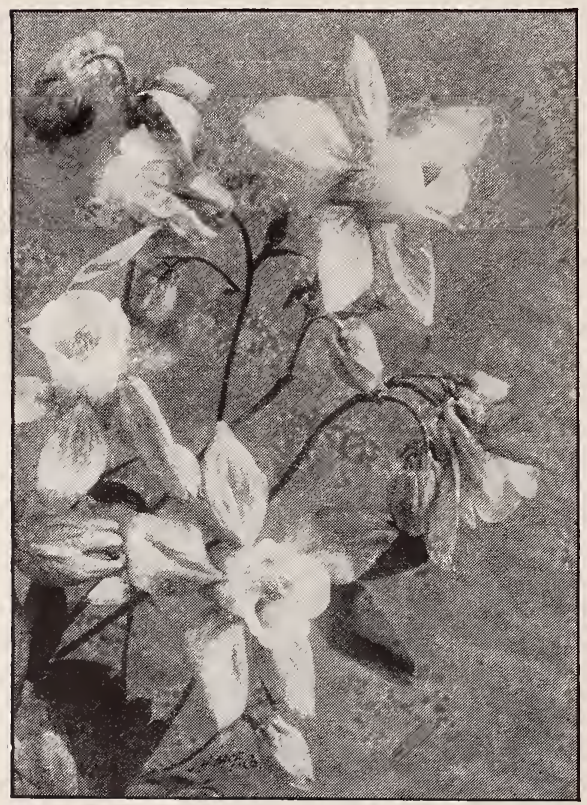

Aquilegia chrysantha double rose colored flowers of the most pleasing character. The foliage also is attractive, and the whole plant very beautiful, growing, as it does, to a heightlof 2 to 3 feet.

\section{Chrysanthemum}

Not the pampered and petted greenhouse Japanese varieties, but the beautiful dwarf pompon varieties that keep the garden blazing until long after early frosts. White, yellow, orange, deep red and brownish crimson, all are included in the mixed colors in which we supply these excellent garden ornamentals.

\section{Aquilegia Canadensis. Columbine'}

Peculiarly shaped red and yellow flowers, held on delicate stems above attractive foliage, and blooming in spring ; particularly useful in rocky places and dry corners. Never growing over 12 inches in height. 


\section{Aquilegia chrysantha. Golden-spurred Columbine}

A stronger-growing variety, with bright yellow flowers, attractive and valuable in its place.

\section{Delphinium, Tall Improved English. Larkspur}

If we were asked to name the handsomest and most satisfactory perennials grown, we should be tempted to say our first choice is Tall Improved English Delphiniums, for they are stately and picturesque, with long, graceful spikes of -blooms of every imaginable shade of blue, varying from the palest sky tints to deepest and most exquisite hues of torqu o is e. Their blooming season is an exceptionally long and continuous one, a bed of Delphiniums being in constant bloum.

In lines, as a background to the hardy border, or in groups of four or five at intervals, the effect is splendid. They are pleasing in beds, or grown in masses, or in large groups of separate colors. Planted amongst shrubbery, a most gorgeous effect may be had. If the spikes are removed when the plant is through flowering, fresh growth is made and a succession of flowers may be expected. The culture of Delphiniums is of the simplest. They are happy in any soil and position, but show the best results in rich, friable loam. In very dry weather a good soaking of water is highly beneficial.

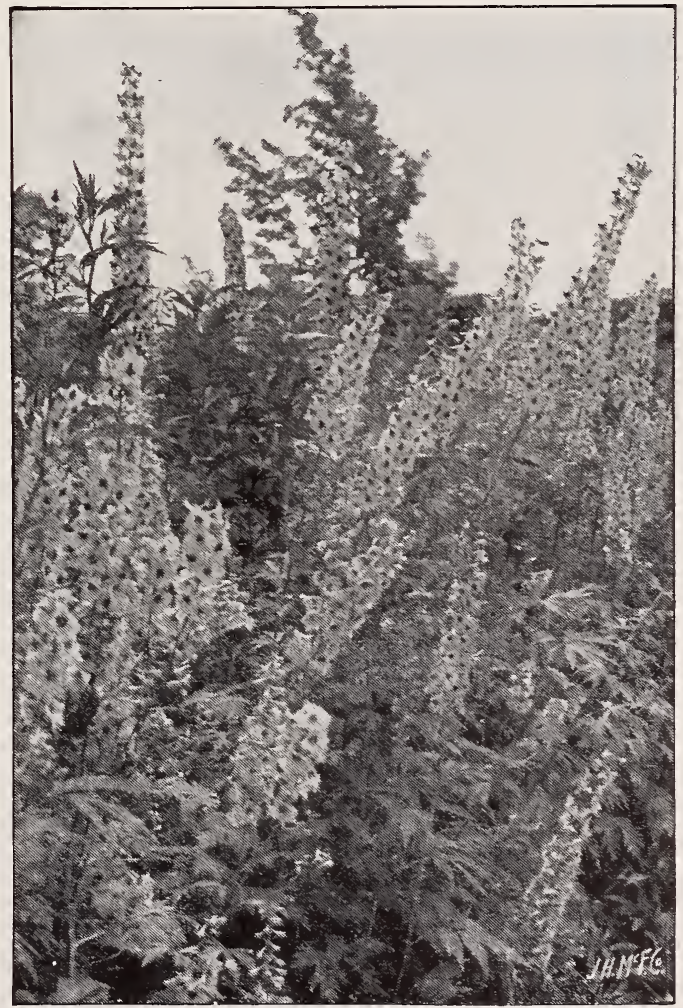

Delphinium 


\section{Peter's Nursery Co., Knoxville, Tenn}

\section{Digitalis purpurea, var. gloxinioides. Foxglove}

One of the old-fashioned plants that is now distinctly in the new fashion. In the great formal gardens about the homes of wealthy people the Foxglove is always found. It has an upright habit, with tall spikes of bell-shaped flowers, ranging in color from white to rose and purple, growing up to 3 feet in strong ground.

\section{Rudbeckia laciniata. Golden Glow}

Few plants have attained the instant popularity of this strong-growing bloomer, which makes the border golden in August and until frost. The flowers are like small dahlias, are borne in great profusion on long, strong stems, reaching a height of 6 to 8 feet. The plants will grow in any soil.

\section{Hollyhock (Althea rosea)}

Another old-fashioned favorite of delightful character. The single mixed strain we sell gives long spikes of the beautiful wide-open flowers that are so attractive in a corner of the garden.

\section{IRIS. Fleur-de-1is}

If these plants were only scarce and hard to grow, so that they required the same petting and care as does an expensive orchid from Borneo or South America, people would travel miles to see them. With just as much richness of color as the finest orchid, they are also easy to grow, take care of themselves, bloom freely, and are altogether desirable. We offer three classes.

Iris Germanica. GeriIAN IRIS. In mixed colors, with rather globular flowers of the most striking combinations and hues.

Iris Kæmpferi. JAPANESE IRIS. Having flat, outspread flowers of extraordinary attractiveness and oddity of coloring.

Iris Florentina. ORRIS ROOT. White flowers, tinged with lavender.

\section{Marshmallow (Hibiscus Moscheutos)}

In a somewhat damp location this beautiful native flower will produce a gorgeous show for several weeks in the latter part of summer. The flowers are clear pink, and there is also a variety with a crimson eye and white petals. Both sorts are beautiful and desirable.

\section{Pink, Scotch or Garden (Dianthus plumarius)}

One of the finest of the "Grandmother's Garden" flowers. The foliage is grass-like; the flowers are double white and double pink, produced in May, and having the most aromatic fragrance.

\section{Plumbago Larpentae, Leadwort}

A rather dwarf plant, bearing bright blue flowers throughout the summer. Excellent for the edging of beds and borders, and for its distinct coloring and pleasant foliage. 


\section{Helps to a Beautiful Home}

\section{Peonies}

Another instance of how the old-fashioned garden has become newfashioned. For many years forgotten, and grown only in odd corners, of late the Peony has become a very fashionable flower, and a national society has been formed to describe and exploit it. Meanwhile any one may have magnificent Peonies who will plant a half-dozen of our mixed varieties, which will rapidly develop into strong, rounded plants, to be covered in spring with great rose-like flowers, ranging from white to deep red. Rich ground and an abundance of water will mean prosperity to the Peonies.

\section{PHLOX, HARDY PERENNIAL}

The Hardy Perennial Phloxes have an exquisite beauty all their own, and for general usefulness no plant surpasses them. For cutting, their long, graceful spikes are very showy, and possess a delicious fragrance Hardy Phloxes are most effective when planted in groups of separate colors, but are also used in rows. In color they range from purest white to deepest crimson.

Hardy Phloxes succeed in any kind of soil, but thrive best in rich, highly cultivated ground, and aregreatly benefited by a liberal mulching of wellrotted manure in spring. They do best if planted in the fall, but will yield good results by spring planting. If the first spikes are removed they will bloom again later in the season, and the later flowers are often the handsomest. If the clumps are taken up in the fall, divided and replanted, the new plants will have more room and will be more

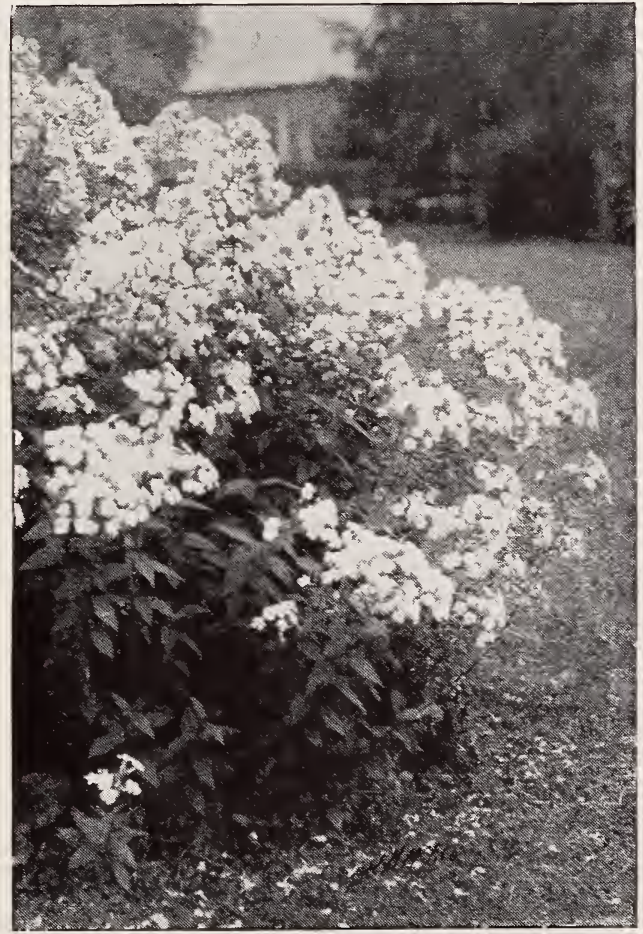

Perennial Phlox 


\section{Peter's Nursery Go., Knoxville, Tenn.}

strong and perfect. We have many varieties, but none compare with the four gorgeous kinds offered below.

Phlox, Miss Lingard. Undoubtedly the best Phlox in cultivation. It produces immense heads of beautiful white flowers in June, and blooms again in September and October. The foliage and habits are splendid, and absolutely free from attacks of red spider.

P. Coquelicot. A most magnificent, vivid orange-scarlet, with a purple center. One of the finest for bedding, and of all the colored Phloxes the most brilliant.

P. Champs-Elysees. A rich, royal purplish crimson.

P. Obergartner Wetteg. The finest of the light shades. Exquisite light rose, shading almost to white in center, with a red eye.

\section{Poppies, Oriental}

Imagine the most beautiful bed of common Poppies you have ever seen, and then conceive, if you can, of the same effect, only ten times richer, grander and more gorgeous, and you have a faint conception of a bed of Oriental Poppies. Nothing can compare with them. No one can imagine anything quite so handsome.

The foliage is beautiful, and the flowers 4 to 6 inches across, are borne gracefully aloft on stems 2 feet long, and grow in all shades of red, from the palest salmon tint to the deepest scarlet. We have three distinct varieties which are handsomer than and superior to all the others, which we grow in large quantities, but have a small lot of other mixed shades on hand.

Unlike common Poppies, the Oriental varieties are very useful as cutflowers, and remain fresh several days after cutting. Oriental Poppies have been accused of being rather hard to establish, and, while we admit that they cannot be classed among the "can't-be-killed" varieties, with a little extra care and attention they thrive mightily, and are one of the most persistent perennials. They love rich soil and lots of sun. The soil may be of any kind except damp and swampy. The foliage dies down when the plant is throukgh blooming, but starts in to grow again in the fall. They may be planted either in the spring or fall, and are effective in rows, but the most striking effects are to be obtained by planting them in beds of separate colors.

\section{Poppy, Oriental}

The type. A rich, glowing scarlet that brings to mind all we have ever heard of the sensuous, mysterious beauty of the far East.

\section{Poppy, Pink Beauty}

More dainty in color effect, but just as royally magnificent. Grows on long stems 3 feet high. 


\section{Helps to a Beautiful Home}

\section{Poppy, Scarlet Giant}

Fiery scarlet, with glittering black blotch at base of petals ; gorgeous and distinct. $35 \mathrm{cts}$. each, $\$ 3.5$ o per doz.

\section{Stokesia Cyanea}

A rarely beautiful plant, bearing a large and extremely handsome blue flower of a most attractive form; grows about one foot high, and is a strikingly valuable addition to the old-fashioned garden.

\section{Sunflower, Double (Helianthus multiflorus plenus)}

In late summer and early fall this plant will provide a blaze of gold and also an opportunity to cut great quantities of beautiful flowers, double and handsome, and entirely free from the coarseness ordinarily associated with the name of Sunflower. Any ordinary soil will produce good results with this Sunflower, which grows 3 to 4 feet in height.

\section{Sweet Lavender (Lavandula vera)}

The delightful old garden plant, with silvery gray and fragrant foliage, distinguished for its exquisite odor. In the garden it forms a most attractive low hedge or an edging to a flower bed.

\section{Sweet William (Diantbus barbatus)}

In a certain northern park garden the chief glory of midsummer is the display of Sweet William. Planted in rich soil it has grown to extraordinary vigor, and thousands of people are attracted to its gorgeous bloom. We can furnish six distinct named varieties, good either separately or in mixture, as one of the very best things in the hardy border.

\section{Tiger Lily (Lilium tigrinum)}

Some of the Lily family are reluctant to establish themselves in the garden, but the old-fashioned, bright red-spotted Tiger Lily will grow anywhere, spread rapidly, and always furnish a striking note of color.

\section{Tritoma}

Sometimes called the "Red-hot Poker" plant. Produces long spikes of the most brilliant orange-scarlet flowers in profusion from midsummer until frost ; is, indeed, a very exclamation point in the garden because of its form and color.

\section{Violet, California}

The large, fragrant, blue flowers of this exquisite Violet make it a well-deserved tavorite. No old-fashioned garden is complete without a clump of this fragrant favorite. 


\section{Ors Peter's Nursery Go, Knoxille, Tenn.}

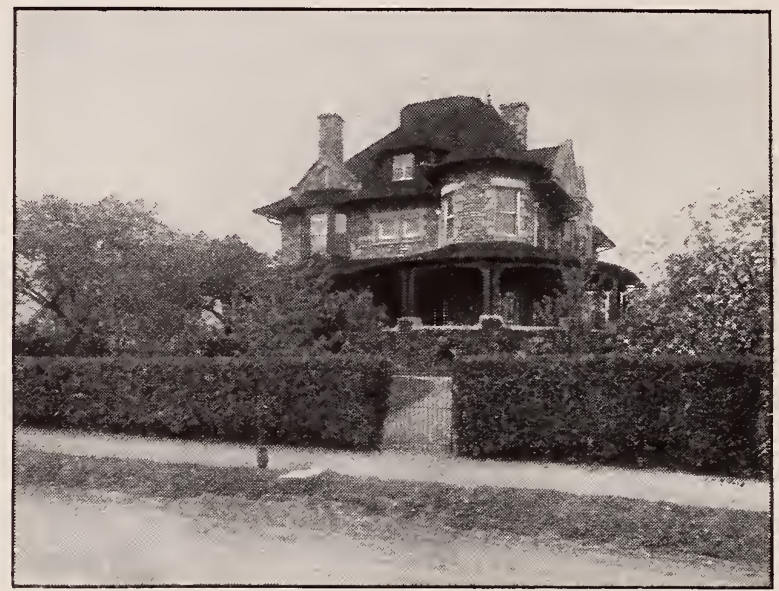

Hedge of Amoor River Privet

\section{Ornamental Hedge Plants}

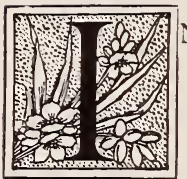

$\mathrm{N}$ addition to the Hedge Plants referred to on former pages, we have a splendid assortment of both evergreen and deciduous plants for that purpose which cannot be surpassed for quality anywhere. No matter what kind of Hedge you want,-for ornament, shelter or defense,write us; we shall be glad to meet your needs. Our list includes :

\section{Privet, Amoor River (Ligustrum Amurense)}

This desirable hardy evergreen is the very best all-round ornamental hedge plant in cultivation, and is used more for this purpose than any other plant. It can be trimmed in any shape desired, and the oftener that it is trimmed the more compact it grows. It can be trimmed in all kinds of fancy and fantastic shapes, and is very effective as a solid wall. We have seen it trimmed as a fence with turned column posts with perfect green balls on top and with fine arches of green over the gateways. It will make a 6- to 9-foot hedge the third year, with proper attention. It is also good to make an open hedge or screen without trimming.

Set plants from 8 to I 2 inches apart in the row ; cut them back to 6 inches when setting, in order to make them start a compact growth from the ground. In trimming, let them make a growth of from 4 to 6 inches and then cut back half and continue this until it is of the desired height, and then leave only half an inch at each trimming. 
We shall be pleased to give you expert advice in all of the details of setting and future care.

It is perfectly hardy, withstanding heat, cold and drought equally well, and grows well in shaded situations. Nothing improves the appearance of a place more than the judicious use of hedges, and this fact is just beginning to be appreciated to the extent it should. The demand has grown to such an extent that it is with the greatest difficulty that we are able this year to offer the plants in sufficient quantity to supply our growing demand. However, we have a very large block of thrifty, wellbranched specimens which we guarantee to give perfect satisfaction in every way. Our stock should not be confounded with the inferior stock so often handled by agents and dealers. We grow our own stock.

The Amoor River is of a bright, glossy green color, which it $r \in t a i n s$ throughout the entire year, which no other hedge plant, except the Boxwood, does.

2 to $3 \mathrm{ft} . \ldots \ldots \ldots \ldots \ldots$ per 100, $\$ 35$ per $\mathrm{r}, 000$

\section{Spruce, Norway}

For evergreen hedges, screens or shelter-belts, the Norway Spruce stands preëminent. It is a rapid grower and of a rich, dark green, making a thick, dense hedge. Stands shearing well and can be kept down to any height.

\section{Arborvitae, American}

Makes a splendid hedge, as it stands shearing well and makes a thick, compact growth. Evergreen, but turns somewhat brown in winter, changing again to a lively green early in spring.

\section{Berberis Thunbergii}

Makes a handsome deciduous hedge which retains its beauty in winter, as the bare twigs are loaded with a profusion of bright coral-red berries. It grows so thickly that in winter it is a mass of matted branches, fulfilling its purpose as a hedge as well as in summer.

\section{Boxwood}

Indispensable for the old-fashioned garden, in which it is used to make borders and edgings.

\section{Althaea (Rose of Sharon, Hibiscus)}

A beautiful flowering shrub which can be used for hedge purposes with great success by training and pruning.

\section{Mock Orange}

Makes a splendid tall screen, covered in spring with a wealth of beautiful blossoms which are delightfully fragrant. 


\section{Peter's Nursery Go., Knoxille, Tenn}

\section{Rosa rugosa (Japanese Rose)}

Peculiar, rough foliage, which in itself is beautiful, apart from the handsome single pink or white roses. Will thrive at the seaside, where no other shrub will grow. It retains its beauty in winter by being covered with great clusters of bright red hips resembling small crab-apples.

\section{Spiraea Thunbergii}

Although commonly planted as a shrub, this makes a beautiful hedge particularly in spring, when it is fairly covered with its handsome sprays of white flowers. The foliage is of a bright lively green, which in autumn turns to brilliant shades of red and yellow.

\section{Roses}

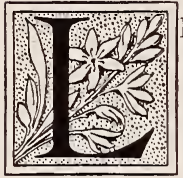

ITTLE need be said to any intelligent American of the value and beauty of this family, certainly preëminent among all the flowers. The Rose-plantings of the people, however, have been too much of tender, greenhouse-grown plants, hardly able to hold up their delicate heads long enough to give pretense of being alive. We offer instead strong fieldgrown plants, vigorous, full of outdoor snap and ready to grow and bloom promptly when received. The list of varieties appended is select. covering only desirable varieties.

Purchaser's selection, 25 cts. each, $\$ 2.50$ per doz., $\$ 20$ per 100 . Our selection, 20 cts, each, $\$ 2$ per doz., $\$ 15$ per 100

BRIDE. A very beautiful white tea or monthly Rose grown largely by the florists, but also excellent in the garden. Requires some protection in the far North.

CLOTHILDE SOUPERT. This is a polyantha, or cluster Rose, producing great quantities of dainty creamy white and rose flowers. It is always in bloom, and makes a fine small bush.

GENERAL JACQUEMINOT. The standard of beauty in deep crimson Roses. A strong grower and perfectly hardy, reaching, as it obtains age and strength, a height of 4 to 5 feet. In June is covered with its glorious flowers, and again in early fall a more sparing bloom is provided. The buds are as beautiful as the open flowers.

KAISERIN AUGUSTA VICTORIA. A delightful creamy white hybrid tea Rose of the most pleasing form and vigorous growing habit. It blooms freely and requires very little protection, except in the extreme North.

LA FRANCE. The most beautiful of all pink Roses, having a distinct form, distinct foliage, and distinct fragrance. The flowers are beautiful in bud or open; are large and of the most attractive character. 


\section{Helps to a Beautiful Home}

METEOR. The finest dark red tea Rose. Of moderate growth, beautiful in bud, and of a strikingly rich color.

MAMAN COCHET. A tea Rose of beautiful rosy pink color, fine form and strong growth. The flowers reach a large size, and are borne on stems with healthy and robust foliage.

PAUL NEYRON. Perhaps the largest of all Roses. Its immense pink flowers are produced in June, and sometimes late in the fall, on an upright and vigorous bush.

CRIMSON RAMBLER. A wonderful introduction from Japan, which has established its brilliant crimson flowers in immense clusters all over the country as the standard of beauty in climbing Roses. Perfectly hardy and a most wonderful bloomer in June.

EMPRESS OF CHINA. A robust and rapid-growing climber, and producing soft red flowers of good size.

CLIMBING CLOTHILDE SOUPERT. Fine blooming white climber, with flowers of a particular excellence of the ordinary Clothilde Soupert. It is the only Rose of its character.

MARECHAL NIEL. In thesouth this Rose is a universal household favorite, being as distinct in its way as La France, and of far greater vigor because of climbing habit. Its foliage is the richest green, and its magnificent flowers of clear yellow are delightfully scented. It is not hardy without protection north of Atlanta, but can be easilv wintered over with a little care.

BABY RAMBLER. An interesting variation of the Rambler type, for while it provides flowers of the same rich crimson in large

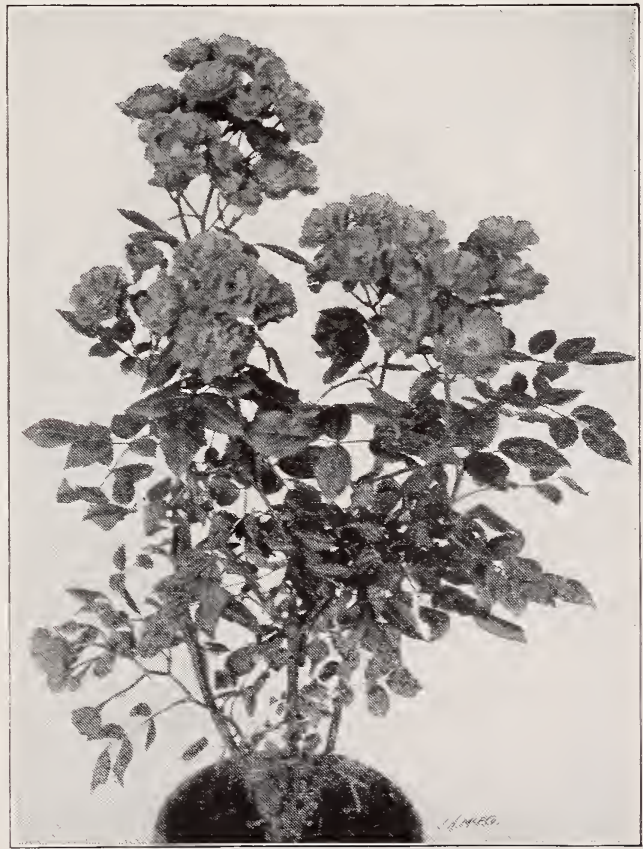

Baby Rambler Rose 


\section{Peter's Nursery Go., Knoxville, Tenn.}

Baby Rambler Rose, continued

clusters, they are borne on a dwarf plant of rounded and pleasing character. Unlike the Crimson Rambler, the Baby Rambler blooms repeatedly, and it is a valuable introduction.

GARDENIA. A very interesting hybrid of the Wichuraiana, bearing single yellow flowers and having foliage of the most distinct character. It is a trailing rose, suitable for covering rocks, banks, fences, etc.

UNIVERSAL FAVORITE. Another Wichuraiana hybrid of trailing or creeping habit, but having large pink flowers.

\section{Dahlias}

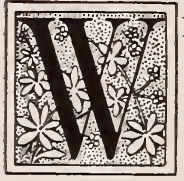

HILE the Dahlia is not hardy, it is so beautiful as to be worthy the little trouble required to lift its roots about the time of frost and give them as much care as potatoes require. Put into the ground the next spring, the roots will soon develop into a handsome bush, covered from July until frost with a profusion of the most beautiful flowers. The modern varieties differ materially from the old and comparatively coarse sorts, the blooms produced by which were not at all pleasing. We name a selection of satisfactory varieties.

$$
20 \text { cts. each, } \$ 2 \text { per doz., } \$ 20 \text { per } 100
$$

Nymphæa. Pink and white, and as beautiful as a water lily. Mrs. Hartong. An attractive light fawn-color; very double. Mrs. Bryan. Delicate lavender shade, with pleasing form.

A. D. Livoni. Rich, deep pink color, and very symmetrical and pleasing form.

Miss Dodd. Pure yellow flowers of the most pleasing character.

Bon Ton. A two-color sort, the flowers being red, tipped with white. Princess Matilda. Pure white flowers of the most striking character.

Don't think that because Peter's Nursery Company is not hoary with age, it cannot serve you well. We are free from prejudice and from old stock to work off; we grow and buy and ship only the best, and are giving good service. Therefore, come to us for helps to a beautiful home-we are truly helpful!

\section{PETER'S NURSERY CO., Knoxville, Tenn.}




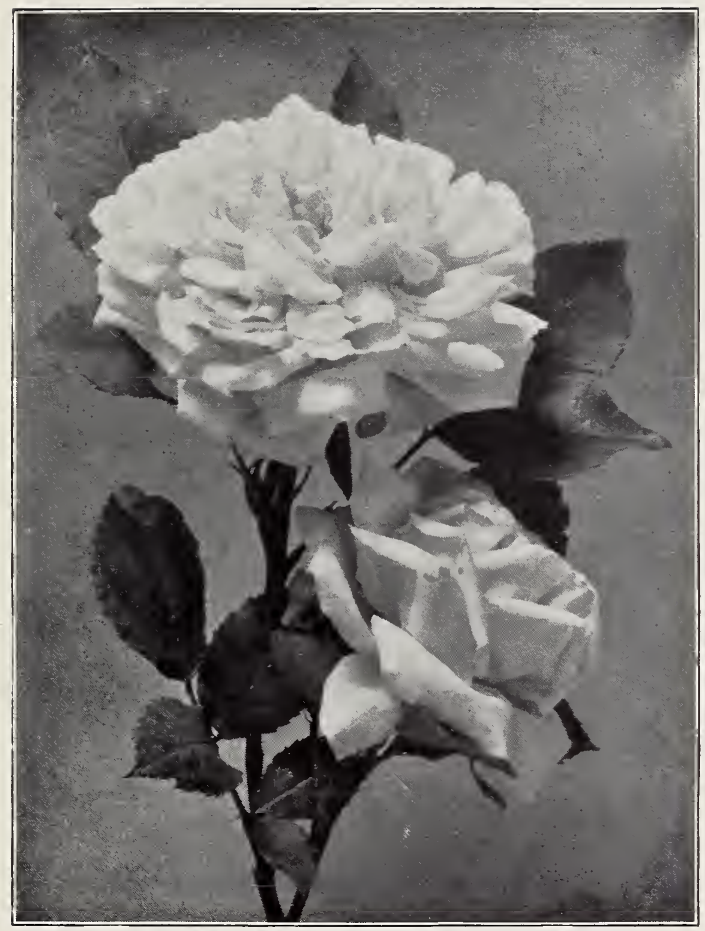

Kaiserin Augusta Victoria Rose (see page 30 ) 


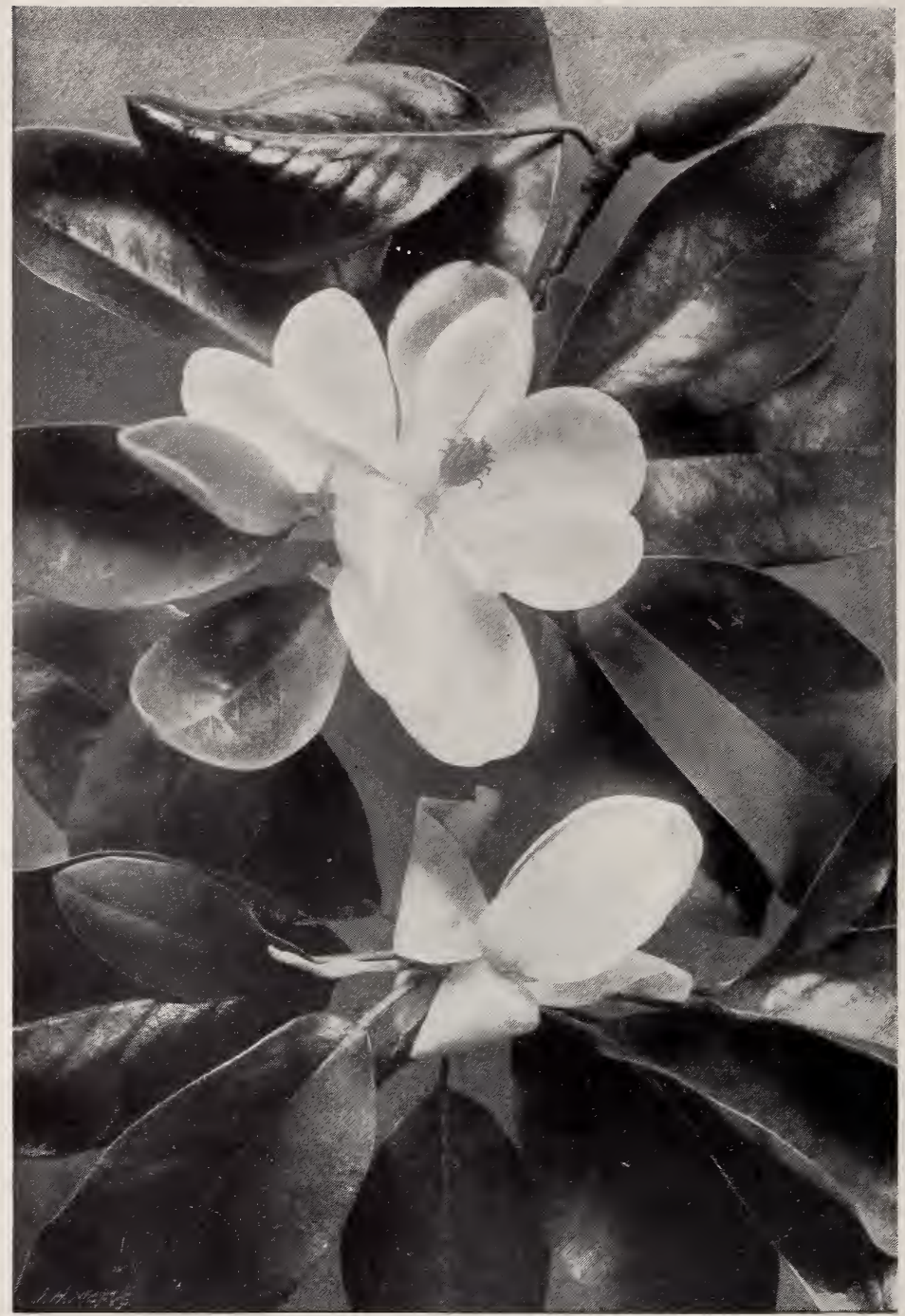

Magnolia grandiflora (see page 16) 